\title{
UJI KESUKAAN DAN KELAYAKAN USAHA PRODUK NUGGET IKAN LELE
}

\author{
Ismawati $^{1 * *}$ Rika Diananing Putri ${ }^{2)}$ \\ Universitas Wiraraja Sumenep, ismawati@wiraraja.ac.id \\ Universitas Wiraraja Sumenep, rikadepe@ wiraraja.ac.id
}

\begin{abstract}
ABSTRAK
Ikan lele merupakan salah satu sumber protein yang relatif lebih murah dibandingkan daging. Produksi ikan lele mengalami peningkatan setiap tahunnya. Untuk mengimbangi jumlah produksi yang meningkat maka perlu dilakukan upaya diversifikasi produk olahan ikan lele salah satunya adalah nugget. Nugget termasuk makanan siap saji yang dikonsumsi oleh masyarakat tingkat menengah. Dalam usaha produk pangan salah satu faktor penentu keberhasilan adalah mutu organoleptik yang dapat diukur melalui Uji kesukaan terhadap parameter organoleptik. Parameter organolepti yang diukur dalam penelitian ini adalah tekstur, aroma, rasa, kenampakan dan warna. Untuk mengetahui layak tidaknya usaha produksi nugget ikan lele maka perlu dilakukan analisis kelayakan dalam hal ini dilakukan analisis BEP dan RCR. merupakan salah satu cara untuk mengetahui mutu suatu produk berdasarkan oganoleptik (pancaindra). hasil penelitian menunjukkan bahwa panelis menyukai rasa, aroma, kenampakan dan warna sedangkan pada parameter tekstur panelis menyatakan sangat suka. BEP unit produk akan tercapai jika telah memproduksi 2366 unit produk atau nilai penjualan sebesar Rp 22380000. Nilai pada usaha nugget ikan lele yaitu yaitu 1,2sehingga dinyatakan layak.
\end{abstract}

\section{PENDAHULUAN}

Ikan lele (Clarias gariepinus B.) merupakan salah satu jenis ikan air tawar yang cukup mudah untuk dibudidaya. Ikan lele kaya akan manfaat kesehatan karena mengandung asam lemak serta merupakan sumber protein. Murniyati dkk dalam Justisia dan Adi (2016) ikan lele kaya akan asam amino esensial yang berupa lisin dan leusin. Ikan lele sebagai sumber protein yang murah jika dibandingkan dengan protein hewani yang berupa daging. Produksi ikan lele di Indonesia mengalami peningkatan sejak tahun 2010 hingga 2013. Pada tahun 2011 meningkat 39\% dari tahun sebelumnya, pada tahun 2012 meningkat $30 \%$ dari tahun sebelumnya dan pada tahun 2013 meningkat sebanyak 41,8\% (Tarigan dkk, 2015). Peningkatan produksi lele perlu diimbangi dengan peningkatan konsumsi agar tidak terjadi penurunan harga dan yang dapat mengakibatkan kerugian atau menurunnya pendapatan petani ikan lele.

Upaya yang dapat dilakukan untuk menyeimbangkan antara produksi dan konsumsi adalah dengan diversifikasi produk olahan ikan lele yang salah-satunya adalah nugget. Nugget adalah makanan instan siap saji yang dapat dikonsumsi oleh berbagai kalangan umur mulai dari anak-anak hingga dewasa. Nugget termasuk produk olahan yang mudah diproduksi bahkan dalam skala rumah tangga. Upaya diversifikasi produk olahan hasil perikanan juga dimaksudkan untuk meningkatkan nilai tambah produk hasil perikanan. Hal lain yang juga penting dalam diversifikasi olahan hasil perikanan adalah mengenalkan produk perikanan kepada masyarakat konsumen Indonesia bahwa hasil perikanan merupakan sumber protein yang tidak kalah jika dibandingkan dengan protein daging yang harganya relatif lebih mahal. Pengenalan produk hasil perikanan merupakan salah satu upaya untuk meningkatkan konsumsi ikan masyarakat Indonesia yang masih rendah jika dibandingkan dengan masyarakat Malaysia. Konsumsi ikan masyarakat Malaysia sebesar 55,4 kg/kapita pertahun dan di Indonesia 31,5 kg/kapita pertahun (Kementerian Kelautan dan Perikanan, 2011).

Untuk memulai suatu usaha olahan pangan diperlukan analisis produk khususnya analisis kesukaan konsumen. Tingkat kesukaan konsumen merupakan faktor utama dalam menjamin keberlanjutan usaha. Faktor lain yang tidak 
kalah penting adalah analisis kelayakan usaha agar dapat menunjang keputusan pelaku usaha dalam memilih suatu usaha yang dapat memberikan manfaat ekonomi. Penelitian ini mengkaji tingkat kesukaan konsumen terhadap nugget ikan lele serta analisis kelayakan usaha. Uji tingkat kesukaan uumumnya adalah uji terhadap kesukaan produk berdasarkan organoleptik.

Nugget termasuk olahan yang populer dimasyarakat sehingga memiliki prospek yang sangat strategis dalam usaha produk olahan. Burhan dalam Thalib (2011) menyebutkan bahwa nugget termasuk produk olahan yang dikonsumsi oleh masyarakat tingkat ekonomi menengah. Pada awalnya nugget diproduksi dengan bahan baku daging yaitu daging sapi dan daging ayam. seiring dengan perkembangan waktu, dinamisnya kebutuhan konsumen dan respon pasar yang cepat saat ini sudah mulai beredar nugget dengan tambahan bahan lain atau disebut dengan nugget komposit. Rusdiana dan Mushollaeni (2009) mengemukakan bahwa nugget komposit dari ampas tahu dan ikan tongkol menghasilkan produk terbaik dengan penambahan $100 \mathrm{~g}$ ampas tahu dan memiliki kandungan protein $15 \%$ dan kalsium $460 \mathrm{mg}$ per $100 \mathrm{~g}$ bahan.

\section{METODE PENELITIAN}

Tahapan dalam penelitian diantaranya adalah tahap pembuatan nugget ikan lele, uji kesukaan panelis terhadap nugget ikan lele dan dilanjutkan uji kelayakan usaha. Uji kesukaan yang dilakukan adalah kesukaan dari panelis terhadap parameter warna, aroma, tekstur, rasa dan kenampakan nugget ikan lele.

Untuk mendapatkan data penilaian panelis digunakan kuesinoner penilaian. Kuesioner yang digunakan adalah kuesioner tertutup dengan memberikan skala penilaian dari angka 1-5 terhadap mutu organoleptik nugget ikan lele. Angka1 menunjukkan skala penilaian sangat tidak suka, angka 2 tidak suka, angka 3 agak suka, angka 4 suka dan angka 5 menunjukkan nilai sangat suka. Semakin besar nilai angka yang diberikan maka semakin tinggi tingkat kesukaan panelis terhadap produk nugget ikan lele.

Panelis yang memberikan penilaian pada produk nugget ikan lele adalah panelis yang tidak terlatih. Panelis tidak terlatih adalah panelis yang tidak memiliki sensivitas tinggi maupun sedang sebagaimana panelis ahli maupun panelis terlatih, panelis tidak terlatih hanya untuk memberikan respon suka atau mau menggunakan suatu produk (Wahyuningtias dkk, 2014). Uji tingkat kesukaan produk dilakukan di lokasi terpusat yaitu SMK dan MA Alkarimiyah Desa Beraji Kecamatan Gapura Kabupaten Sumenep.

Tahapan dalam uji kesukaan panelis dimulai dari pembuatan nugget dan selanjutnya dilakukan uji kesukaan dengan melibatkan panelis tidak terlatih. Bahan yang digunakan dalam pembuatan nugget yaitu: fillet ikan lele, tepung terigu $10 \%$ (berat fillet), merica bubuk, garam, penyedap, telur, bawang merah, bawang putih dan tepung roti.

Analisis kelayakan ditinjau berdasarkan kriteria break event point (BEP) dan revenue cost rasio ( $\mathrm{RCR})$. Prawirosentono dalam Sabrin (2015) break event point dapat dihitung berdasarkan aspek pemasaran dan penjualan. Berdasarkan aspek pemasaran adalah dilihat dari besarnya volume penjualan yang mencapai tingkat penghasilan yang sama dengan total biaya. Aspek penjualan adalah tingkat penjualan barang ataupun jasa yang mana sampai pada perusahaan tidak mendapatkan untung akantetapi tidak rugi atau impas. Revenue Cost Rasio (RCR) adalah perbandingan antara total penerimaan dan biaya total, apabila hasil analisis RCR nilainya 1 maka usaha yang dikelola impas, apabila <1 maka suatu usaha tidak layak dan dapat dikatakan layak apabila >1 (Soekartawi dalam Hairun dkk, 2016). 


\section{HASIL DAN PEMBAHASAN Tingkat Kesukaan Panelis}

Uji tingkat kesukaan penting dilakukan oleh industri pengolahan pangan dengan tujuan pengembangan produk berdasarkan penilaian tingkat kesenangan konsumen terhadap produk yang sudah ada dan ingin dikembangkan maupun terhadap produk baru.

Rerata hasil uji tingkat kesukaan panelis terhadap produk nugget ikan lele sebagaimana disajikan pada Gambar 1.

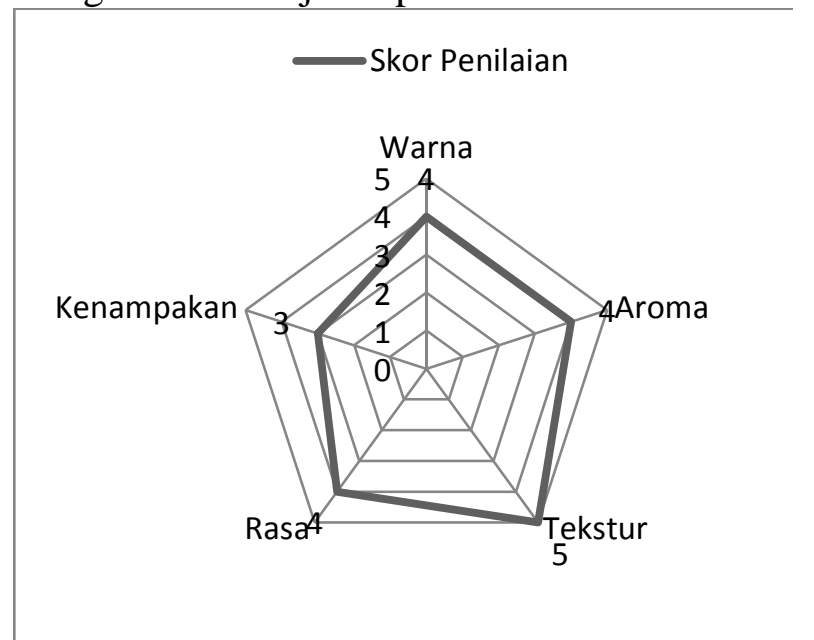

Gambar 1. Rerata Nilai Kesukaan Panelis Terhadap Nugget Ikan Lele

Berdasarkan Gambar 1 maka dapat dikatakaan bahwa panelis sangat menyukai tekstur nugget ikan lele. Ikan lele termasuk ikan air tawar yang memiliki tekstur daging lembut sehingga mempengaruhi tekstur nugget menjadi lembut dan disukai oleh panelis. Hal ini sejalan dengan penelitian yang dilakukan oleh Nurlaila dkk (2017) hasil uji organoleptik terhadap nugget dari berbagai bahan dasar hewani menunjukkan bahwa panelis menyukai nugget dengan tekstur yang lembut.

Panelis dalam penelitian ini memberikan nilai rerata 4 pada aroma yang artinya adalah panelis menyukai aroma nugget ikan lele. Aroma merupakan salah satu faktor penting dalam mutu pangan yang erat kaitannya dengan penerimaan konsumen. Winarno (1997) mnyebutkan bahwa mutu pangan tidak hanya dinilai berdasarkan komponen gizi atau kimia akan tetapi mutu organoleptik juga merupakan faktor yang penting.

Dalam pembuatan nugget tepung dapat berfungsi sebagai bahan pengisi. Penambahan tepung dalam pembuatan nugget selain sebagai bahan pengisi juga untuk menambah bobot dan meningkatkan volume sehingga dapat menekan biaya produksi. Akan tetapi persentase penambahanbahan pengisi harus diperhatikan karena dapat mempengaruhi mutu organoleptik nugget yang dihasilkan.

Dalam penelitian ini bahan pengisi yang digunakan adalah tepung terigu dengan persentase $10 \%$. Hal ini sejalan dengan yang dilakukan Rahmawati dan Budiyanto (2017) dalam pembuatan nugget daging itik afkir faktor yang mempengaruhi tingkat kesukaan panelis terhadap aroma nugget adalah dosis atau persentase penggunaan tepung sebagai bahan pengisi sedangkan kombinasi berbagai tepung tidak memberikan pengaruh pada aroma sebab dalam pembuatan nugget bahan baku utamanya adalah daging sehingga jenis tepung yang digunakan tidak berpengaruh pada aroma dengan batas penambahan tepung maksimal $20 \%$ dari bahan utama. Penambahan tepung $10 \%$ tidak menghilangkan aroma khas ikan lele sehingga panelis menyukai nugget ikan lele.

Gambar 1 menunjukkan bahwa penilaian panelis terhadap rasa nugget ikan lele adalah angka 4 yang menunjukkan ekspektasi suka terhadap produk. Dalam penelitian ini selain peggunaan tepung $10 \%$ sebagai bahan pengisi, juga digunakan bumbu penyedap, garam dan rempah yaitu bawang merah, bawang putih dan merica untuk meningkatkan cita rasa nugget ikan lele akan tetapi tidak menghilangkan rasa khas dari ikan lele.

Kenampakan nugget dalam penelitian ini adalah kenampakan dari segi bentuk. Kenampakan (bentuk) nugget ikan lele dinilai dengan angka 3 oleh panelis yang artinya agak suka. pada umumnya 
nugget memili bentuk yang bervariasi seperti bentuk hati, bentuk bentuk balok dan lain-lain. Dalam penelitian ini nugget dibuat dengan bentuk lingkaran sehingga jika dibandingkan dengan produk nugget yang sudah ada maka daya tariknya kurang. Oleh sebab itu panelis memberikan nilai 3 pada kenampakan nugget ikan lele.Nurlaila dkk (2017) mengemukakan bahwa kenampakan adalah faktor paling pertama dalam penilaian konsumen yang mana konsumen akan cenderung memilih produk yang kenampakannya menarik.

Panelis memberikan nilai 4 pada warna nugget. Nilai tersebut menunjukkan panelis menyukai warna nugget ikan lele. Penilaian terhadap warna nugget ikan lele adalah warna dalamnya setelah melalui proses penggorengan. Warna dalam nugget umumnya berbeda tergantung bahan yang digunakan oleh sebab itu dalam penelitian ini yang dinilai adalah wara dalam. Hakim (2014) mengemukakan bahwa panelis dalam penelitiannya yaitu formulasi nugget ikan tongkol dan jamur tiram memberikan nilai suka pada nugget dengan warna kuning kecoklatan setelah digoreng.

\section{Kelayakan Usaha Nugget Ikan Lele}

Biaya tetap yang perlu dikeluarkan dalam usaha produksi nugget diantaranya tempat produksi, instalasi listrik, pembelian alat. Perhitungan kelayakan usaha pada penelitian ini mengasumsikan biaya yang digunakan adalah biaya sendiri dan tempat usaha diasumsikan milik pribadi sehingga instalasi listrik juga diasumsikan terhubung dengan rumah induk milik pribadi. Adapun biaya tetap dalam usaha nugget ikan lele sebagaimana pada Tabel 1.

Biaya variabel adalah biaya yang berkaitan dengan output yang akan dihasilkan. Semakin besar output (produk) yang akan dihasilkan maka semakin besar biaya variabel yang harus dikeluarkan. Biaya variabel ini disusun berdasarkan kapasitas produksi 20kg ikan lele per hari sehingga perbulan (20 hari kerja) memproduksi ikan lele $400 \mathrm{~kg}$. Penelitian ini mengasumsikan dalam satu tahun terdiri dari 300 hari kerja.Biaya variabel dalam usaha nugget sebagaimana disajikan pada Tabel 2.

Tabel 1. Biaya Tetap Usaha Nugget Ikan Lele

\begin{tabular}{lr}
\hline Komponen Biaya Tetap & Total Biaya \\
\hline Sewa tempat & 2000000 \\
Instalasi listrik & 600000 \\
Food processor & 750000 \\
Pisau dan telenan & 50000 \\
Penyusutan alat & 330000 \\
Total & 3730000 \\
\hline
\end{tabular}

Tabel 2. Biaya Variabel Nugget Ikan Lele

\begin{tabular}{lrr}
\hline $\begin{array}{l}\text { Komponen } \\
\text { Tetap }\end{array}$ & Biaya & Total Biaya/tahun \\
\hline Ikan lele & & 78000000 \\
Bahan & baku & 1500000 \\
pendukung & & 9600000 \\
Tenaga Kerja & & 750000 \\
Gas Elpiji & & 1000000 \\
Kemasan & & 90850000 \\
Total & \\
\hline
\end{tabular}

Asumsi rendemen nugget ikan lele adalah $100 \%$. Hal ini mengacu pada penelitian Rusdiana dan Mushollaeni bahwa rendemen nugget ikan tongkol dengan penambahan tepung ampas tahu adalah $106 \%$. Dengan menggunakan 20kg ikan lele perhari maka akan didapatkan filet ikan lele sebesar $8 \mathrm{~kg}$. Berdasarkan hal itu jika nugget ikan lele di jual ddalam kemasan isi 200g nugget maka akan didapatkan 40 unit/bungkus nugget ikan lele/hari sehingga dalam satu tahun 12000 unit atau $2400 \mathrm{~kg}$ nugget ikan.

Biaya produksi nugget ikan lele adalah Rp 94580000 sehingga harga jual nugget ikan lele per unit dengan keuntungan 20\% adalah Rp 9458 (9500). BEP unit produk dari usaha nugget ikan lele yaitu 2366 artinya titik impas akan tercapai jika telah memproduksi 2366 unit nugget ikan lele (200 g/unit). BEP rupiah 
tercapai jika mampu memperoleh nilai penjualan Rp 22380000. Nilai RCR nugget ikan lele adalah 1,2 artinya usaha nugget ikan lele memberikan keuntungan sehingga layak untuk diusahakan karena nilai $\mathrm{RCR}>1$.

\section{KESIMPULAN}

Tingkat kesukaan panelis terhadap nugget ikan lele pada parameter tekstur adalah sangat suka sedangkan pada parameter aroma, rasa, kenampakan dan warna menunjukkan bahwa panelis menyukai. Usaha nugget ikan lele akan mencapai titik impas ketika mampu menjual 2366 unit produk (200g/unit) atau mampu memperoleh nilai penjualan sebasar Rp 22380000 dengan harga produk 9500/unit. Usaha Nugget ikan lele dinyatakan layak berdasarkan nilai RCR yaitu 1,2.

\section{DAFTAR PUSTAKA}

Hairun, Suslinawati, Zuraida, Ana. 2016. Analisis Usaha Pembuatan Tempe (studi kasus pada usaha pembuatan tempa Bapak Joko Suwarno) di Kelurahan Binuang Kecamatan Binuang Kabupaten Tapin. Al Ulum Sains dan Teknologi. 2 (2): 44-51.

Kementrian Kelautan dan Perikanan. 2011. Konsumsi Ikan Indonesia.
Nurlaila, S., Agustini, M.D. dan Purdiyanto, J. 2017. Uji Organoleptik Terhadap Berbagai Bahan Dasar Nugget. Jurnal Maduranch. 2 (2). 67-71.

Rusdiana, Endang dan Mushollaeni, Wahyu. 2009. Kelayakan Finansial dan Proses dalam Industri Pengolahan Nugget Komposit.Buana Sains. 9 (2): 191-195

Sabrin. 2015. Analisis Break Event Point pada Produksi Es Balok pada PT. Yanaghi Histalaraya. Jurnal Ekonomi Pembangunan.16 (8): 2733.

Thalib, Ahmad. 2011. Uji Tingkat Kesukaan Nugget Ikan Madidihang (Tunnus albicares). Jurnal Agirisnis dan Perikanan. 4 (1).

Tarigan, Br. Andriani, J.F., Aritonang, Y.E., Sudaryati, E. 2015. Daya Terima Nugget Ikan Lele yang Memanfaatkan Tepung Kacang Merah dan Kandungan Gizinya. Jurnal repositori USU. Palembang. repository.usu.ac.id. Diakses Agutus 2018.

Wahyunningtias, D. Putranto, T.S. dan Kusdiana, R.N. 2014. Uji Kesukaan Hasil Jadi Kue Brownies Menggunakan Tepung Terigu dan Tepung Gandum Utuh. Jurnal Binus Bussiness Review. 5 (1): 57-65. 